\title{
KULT RZYMSKOKATOLICKI WE LWOWIE W LATACH 1945-1991
}

\begin{abstract}
Streszczenie
W artykule przedstawiono wybrane aspekty życia społeczno-religijnego rzymskokatolickiej społeczności Lwowa w Związku Sowieckim w latach 19451991. Kościół katolicki na ziemiach polskich przyłączonych do ZSRS został podporządkowany prawodawstwu komunistycznemu, które walczyło z religią i szerzyło ateizm. Struktury kościelne zostały zlikwidowane, a duchowieństwo i wierni poddani represjom. Pomimo tego Kościół jako wspólnota wierzących trwał oraz wykorzystywał różne możliwości do dalszej działalności. W artykule ukazano postawy lwowskiego duchowieństwa wobec władz sowieckich oraz ich niejawną aktywność duszpasterską wśród wiernych. Szczególną uwagę skupiono na duchownych, którzy stali się symbolami lwowskiego duszpasterstwa po II wojnie światowej. Byli to księża: Karol Jastrzębski, Stanisław Płoszyński, Zygmunt Hałuniewicz i Rafał Władysław Kiernicki, farnciszkanin.
\end{abstract}

Słowa kluczowe: Lwów; katedra lwowska; Ukraina sowiecka; ksiądz Karol Jastrzębski; ksiądz Stanisław Płoszyński; ksiądz Zygmunt Hałuniewicz; Rafał Władysław Kiernicki

\section{Wprowadzenie}

Celem artykułu jest charakterystyka życia społeczno-religijnego rzymskokatolickiej społeczności lwowskiej w Związku Sowieckim okresie 1945-1991. Opierając się na zebranych materiałach oraz relacjach świadków, ukazano działalność Kościoła katolickiego w trudnej rzeczywistości rządów komunistycznych na przykładzie lwowskiej katedry pw. Wniebowzięcia Najświętszej Maryi Panny.

* Ks. Pavlo Khomiak - mgr teologii, doktorant, Wschodnioeuropejski Uniwersytet Narodowy im. Łesi Ukrainki w Łucku (Ukraina)

e-mail: paolochomiak@gmail.com

https://orcid.org/0000-0002-4825-9009 
Kościół działał w Związku Sowieckim na zasadzie instytucji prywatnej, której władze państwowe zezwalały lub zabraniały na zatrudnienie duchownego jako „,pracownika”, dlatego też omawiając kult religijny czy duszpasterstwo przy katedrze lwowskiej, należy prześledzić działalność księży, którzy w latach 1945-1991 posługiwali w tym kościele. We wspomnianym czasie lwowska świątynia katedralna była nie tylko miejscem sprawowania kultu, lecz także pielęgnowania tradycji i kultury polskiej, które na równi z religią skazane były przez władze na wykorzenienie i zapomnienie.

\section{Kościół katolicki w realiach komunistycznego systemu sowieckiego}

W Ukraińskiej Socjalistycznej Republice Sowieckiej w latach 1945-1991 Kościół podlegał - podobnie jak w całym Związku Sowieckim - przepisom konstytucji z dnia 10 lipca 1918 r. (rozdz. 2, art. 13), w których zapisano, że dla zabezpieczenia ludowi pracującemu wolności sumienia, oddziela się państwo oraz szkoły od Kościoła. Prawodawstwo to umożliwiało instancjom państwowym skuteczną walkę z Kościołem. Każdy obywatel miał prawo do działalności antyreligijnej, która cieszyła się pełnym poparciem państwa. Kościół był traktowany jako prywatne stowarzyszenie, rejestrowane przez komitety parafialne zwane dwadcat$\mathrm{kami}^{1}$. Funkcjonowały one wedhug prawa sowieckiego jako jedynie dopuszczalne gremia zarządzające kultem religijnym, przy czym nie miały osobowości prawnej umożliwiającej im administrację własnością kościelną. Wszystko co odnosiło się do kultu i Kościoła, regulowane było jednostronnymi normami ustanowionymi przez państwo i egzekwowanymi według jego woli².

Ateistyczne państwo, jakim był Związek Sowiecki, utrudniało funkcjonowanie tzw. służącym kultu w wypełnianiu posługi. Każda czynność kapłana czy wiernych była praktycznie pod kontrolą władz. Nacjonalizacje majątku kościelnego, zamykanie kościołów, prześladowanie księży i wiernych ograniczały kult i duszpasterstwo, niekiedy wprost je uniemożliwiając, z powodu braku kapłanów. Pomimo tego władze państwowe nie były w stanie zlikwidować religijności obywateli. Było wręcz przeciwnie - im silniejsze prześladowanie, tym żarliwsze życie religijne prowadzili wierni.

${ }^{1}$ Zob. J. Szymański, Dwadcatki - organy wykonawcze organizacji religijnych $w$ sowieckim systemie represji (Obwód Winnicki na Podolu, 1944-1964), „Roczniki Teologiczne”, 50 (2003) z. 4, s. 175-180; W. Osadczy, Kościoła katolickiego na Ukrainie dole i niedole. Doświadczenie, dzień dzisiejszy, problemy i perspektywy, w: Kościót katolicki na Wschodzie w warunkach totalitaryzmu i posttotalitaryzmu, red. A. Gil, W. Bobryk, Siedlce-Lublin 2010, s. 87-108.

${ }^{2}$ Konstytucja Rosji bolszewickiej uchwalona po rewolucji październikowej dnia 10 lipca 1918 r., w rozdziale 2, artykule 13 określała: „W celu zabezpieczenia rzeczywistej wolności sumienia pracujących, Kościół zostaje oddzielony od państwa, a szkoła od Kościoła i uznaje się zupełną swobodę religijnej i antyreligijnej propagandy dla wszystkich obywateli”. A. Bosiacki, Utopia, wtadza, prawo. Doktryna i koncepcje prawne „,bolszewickiej” Rosji 1917-1921, Warszawa 1999; J. Wołczański, Ksiadz Biskup Jana Olszański. Duszpasterz - Patriota-Człowiek, w: Pasterz i twierdza. Księga jubileuszowa dedykowana księdzu biskupowi Janowi Olszańskiemu ordynariuszowi diecezji w Kamieńcu Podolskim, red. J. Wołczański, Kraków-Kamieniec Podolski 2001, s. 9. 
Zakaz uczęszczania na religię i udziału w kulcie dla osób do 18. roku życia oraz likwidacja miejsc kultu sprawiły, że dzieci i młodzież zostały pozbawione dostępu do Kościoła. Pozostawało więc w praktyce tylko katechizowanie w rodzinie. Obiekty sakralne przeznaczano na cele świeckie, często je dewastując, np. urządzając w nich warsztaty, stajnie, magazyny. W wielu przypadkach zamieniano je na sale kinowe, domy kultury czy rozrywki. Już sam ten fakt oddziaływał negatywnie na młodzież, powodując zanik świadomości istnienia miejsc sakralnych, rodząc przyzwyczajenie do nowych ośrodków spotkań i wydarzeń wspólnotowych, mających charakter laicki, a często wprost antyreligijny, kiedy np. w kościołach instalowano muzea ateizmu. Na terenie Ukrainy sowieckiej likwidacja miejsc kultu przebiegała równie intensywnie, jak w innych republikach związkowych ${ }^{3}$.

Od czasu wymuszonego przez NKWD wyjazdu arcybiskupa lwowskiego obrządku łacińskiego Eugeniusza Baziaka ${ }^{4}$ w 1946 r. na Ukrainie sowieckiej nie było biskupa katolickiego. Przed odjazdem abp E. Baziak mianował proboszcza ze Złoczowa - ks. Jana Cieńskiego - wikariuszem generalnym na archidiecezję lwowską. Tamtejszy Kościół podlegał jurysdykcji katolickiego biskupa łacińskiego rezydującego w Rydze, skąd kierowano absolwentów miejscowego seminarium duchownego do pracy duszpasterskiej na terenie Związku Sowieckiego. Ograniczenie jurysdykcji biskupa rzymskokatolickiego na Ukrainie Zachodniej nie było największym problemem dla tamtejszych parafii obrządku łacińskiego. Bardziej dotkliwe było systematyczne i bezkompromisowe likwidowanie parafii i represje duchowieństwa. Procesy te następowały bezpośrednio po sobie - w momencie aresztowania i zesłania do łagrów duchownego władze administracyjne natychmiast zamykały świątynię, likwidując tym samym parafię 5 .

${ }^{3}$ R. Dzwonkowski, Religia i Kościół katolicki w ZSRS 1917-1991. Kronika, Lublin 2010, s. 3337.

${ }^{4}$ Eugeniusz Baziak (1890-1962) - metropolita lwowski, administrator apostolski i ordynariusz w Krakowie. W 1908 r. rozpoczął studia teologiczne na Uniwersytecie Lwowskim. Po święceniach w 1912 r. pracował w parafii Żółkiew, w 1917 r. został kapelanem wojskowym, a od 1919 r. pracował jako prefekt w seminarium duchownym we Lwowie. Po uzyskaniu w 1921 r. doktoratu z teologii przejął obowiązki wicerektora seminarium duchownego oraz był katechetą $\mathrm{w}$ seminarium nauczycielskim. W 1931 r. został proboszczem kolegiaty w Stanisławowie, a w następnym roku protonotariuszem apostolskim. W 1933 r. przyjął sakrę biskupią. Jako sufragan lwowski sprawował urząd rektora seminarium duchownego, asystenta diecezjalnego Akcji Katolickiej i kustosza Kapituły Metropolitalnej. W 1944 r. został arcybiskupem koadiutorem arcybiskupa Bolesława Twardowskiego, po którym jeszcze w tym roku przejął rządy w diecezji oraz przeniósł siedzibę administracji lwowskiej do Lubaczowa. W 1951 r. został także koadiutorem krakowskim, a w razie śmierci ordynariusza (kard. A.S. Sapiehy) w Krakowie, administratorem apostolskim archidiecezji krakowskiej z władzą biskupa diecezjalnego. Faktycznie po śmierci kard. A.S. Sapiehy przejął od 13 grudnia 1956 r. funkcję administratora apostolskiego archidiecezji krakowskiej, następnie papież Jan XXIII mianował E. Baziaka ordynariuszem w Krakowie. Zmarł w Warszawie. M. Rechowicz, Baziak Eugeniusz, w: Encyklopedia katolicka (dalej: EK), t. 2, red. F. Gryglewicz, R. Łukaszyczyk, Z. Sułowski, Lublin 1985, kol. 127.

${ }^{5}$ Z przeszło 400 parafii w archidiecezji lwowskiej w 1939 r. w okresie władzy sowieckiej zostało 7: Lwów - katedra, Lwów - św. Antoniego, Borszczów, Hałuszczyńce, Stryj, Szczerzec, Złoczów. W. Urban, Archidiecezja lwowska, w: Życie religijne w Polsce pod okupacja 1939-1945. 
W 1939 r. dekanat lwowski miejski obejmował 17 parafii, 4 kapelanie, 8 kościołów i kaplic zakonnych oraz 9 innych kościołów. W sumie 38 (32 - Будз) świątynie ${ }^{6}$. Po II wojnie światowej, w 1949 r. we Lwowie nazywanym wcześniej urbs catholicissima władze sowieckie pozostawiły do celów kultu cztery łacińskie świątynie: katedrę pw. Wniebowzięcia Najświętszej Maryi Panny ${ }^{7}$, kościoły św. Antoniego z Padwy na Łyczakowie, św. Marii Magdaleny i Matki Bożej Śnieżnej ${ }^{8}$, a po 1962 r. tylko dwa: katedrę i kościół św. Antoniego.

Metropolie wileńska i lwowska, zakony, red. Z. Zieliński, Katowice 1992, s. 92; M. Buczek, Biskup Jan Cieński - tajemny biskup w Złoczowie, „Kurier Galicyjski” z 17-29.11.2017, nr 21 (289), s. 2021.

${ }^{6}$ B. Modzelewska, W. Osadczy, Lwów. 1 Miasto, w: EK, t. 11, red. E. Ziemann, Lublin 2006, kol. 307; К. Будз, Украӥнська Греко-Католичька Церква у Галичині (1946-1968): стратегіi виживання та опору у підпіллі, Київ 2016, s. 125.

${ }^{7}$ Katedra pw. Wniebowzięcia NMP we Lwowie - ustanowiona w 1412 r. przez Jana XXIII w ramach translacji stolicy metropolitalnej z Halicza do Lwowa. Konsekrowana w 1481 r. Czczono w niej wizerunek Matki Bożej „Łaskawej”. Przed tym obrazem król Jan Kazimierz w 1656 r. złożył tzw. śluby lwowskie. W 1756 r. obraz został umieszczony w ołtarzu głównym, a dnia 11 maja 1776 r. został koronowany przez abpa Wacława Hieronima Sierakowskiego koronami papieskimi. Z tej okazji katedrę lwowską ogłoszono Sanktuarium Matki Bożej Łaskawej. Po II wojnie światowej przewieziono obraz do Polski, a w 1974 r. umieszczono go w ołtarzu głównym prokatedry w Lubaczowie. W 1980 r. obraz poddano konserwacji w Krakowie i złożono w skarbcu katedry na Wawelu. Kopię wizerunku przeznaczoną do prokatedry w Lubaczowie ukoronował na Jasnej Górze 19 czerwca 1983 r. Jan Paweł II, drugą kopię - z katedry lwowskiej, papież ukoronował we Lwowie w 2001 r. М. Бучек, Парафії, костели та каплиці. Львівська область, t. 1, Львів 2004, s. 149; J. Маndziuk, Z dziejów archidiecezji lwowskiej, „Saeculum Christianum”, 2 (1995) nr 2, s. 40-41; I. Platowska-Sapetowa, Cudowny Obraz N.P. Maryi Laskawej z Archikatedry Lwowskiej w Prokatedrze w Lubaczowie, Rzeszów 1991, s. 7-18; J. Wołczański, Bazylika Metropolitalna obrzadku tacińskiego we Lwowie, „Radość Wiary”, (2001) nr 1 (29), s. 10; S. Frucht, Lwów, Lwów-Wrocław 2003, s. 34 .

${ }^{8}$ Kościół św. Antoniego z Padwy - zbudowany w 1630 r. dla franciszkanów konwentualnych na przedmieściu Łyczakowskim, na wzgórzu św. Antoniego w Suchej Woli. W wyniku reform józefińskich klasztor został skasowany. W 1786 r. do kościoła przeniesiono parafię z pobliskiego kościoła śś. Piotra i Pawła, którą obsługiwali od tego momentu franciszkanie. Po ich przymusowej ekspatriacji w 1946 r., we Lwowie pozostał tylko franciszkanin o. Rafał Kiernicki (1912-1995), proboszcz łacińskiej katedry lwowskiej. Dzięki niemu w 1989 r. przybyli do Lwowa franciszkanie z macierzystej Prowincji św. Antoniego i bł. Jakuba Strzemię z Krakowa, którzy zamieszkali przy kościele św. Antoniego, gdzie prowadzą duszpasterstwo parafialne. B. Kaczorowski, Zabytki starego Lwowa, Warszawa 1999, s. 82-86.

Kościół św. Marii Magdaleny i klasztor Dominikanów we Lwowie - wybudowany w $1600 \mathrm{r}$. Zakonnicy prowadzili w nim duszpasterstwo do kasaty józefińskiej w 1784 r. Świątynię oddano do dyspozycji metropolity lwowskiego i pełniła funkcję kościoła parafialnego, przy którym wybudowano plebanię. Kościół służył wiernym do 1945 r. Ponownie otwarto go w 1946 r. Posługę duszpasterska sprawowali w nim ks. Zygmunt Truszkowski (1876-1949), o. Marcin Karaś (1910-2003), o. Rafał Kiernicki OFM Conv (1912-1995), ks. prałat Zygmunt Hałuniewicz (1889-1974), który w marcu 1962 r. otrzymał zakaz celebrowania nabożeństw. W świątyni przekazanej Politechnice Lwowskiej urządzono klub studencki, a następnie „Dom muzyki kameralnej i organowej”. Od 2001 r. w kościele św. Marii Magdaleny odprawiane są nabożeństwa na zasadach odpłatności. 
Lwów był pod względem wyznaniowym bardziej zróżnicowany niż inne miasta Małopolski Wschodniej. Według spisu powszechnego z 1931 r. 63,5\% ludności miasta posługiwało się językiem polskim, 24,1\% jidysz i hebrajskim, a 11,3\% ukraińskim lub ruskim. Podobnie rozkładało się rozwarstwienie wyznaniowe, w którym należy uzwględnić także niewielki procent Ormian i innych wyznań, zwłaszcza ewangelickie. We Lwowie dominowali katolicy obrządku łacińskiego, choć miasto było także stolicą arcybiskupa metropolity greckokatolickiego, którego wierni dominowali na prowincji. Po II wojnie światowej grekokatolicy dominowali liczebnie, natomiast gminy żydowskie zanikły niemal całkowicie wraz z wymordowaniem w czasie wojny ludności żydowskiej liczącej przed wojną ponad 20\% mieszkańców Lwowa.

Ogólnie naszkicowana sytuacja wyznaniowa miasta od czasów przedwojennych, poprzez dwie okupacje, do czasów powojennych pozwala stworzyć tło dla opisania duszpasterstwa ludności rzymskokatolickiej Lwowa identyfikującej się w ogromnej większości z polskością.

\section{Lwowska katedra jako ostatni bastion polskości we Lwowie}

Największym ośrodkiem życia religijnego i patriotycznego we Lwowie, w którym pielęgnowano polską tożsamość narodową po 1945 r., była katedra łacińska pw. Wniebowzięcia Najświętszej Maryi Panny. Była ona jednym z dwóch świątyń w archidiecezji, które pozostawały stale czynne. W katedrze znajdowały się najcenniejsze pamiątki historyczne, a obrządek łaciński cementował więź Kresów z Rzeczpospolitą̧.

Wielką rolę w dziejach Kościoła katolickiego na Kresach Wschodnich odegrali nie tylko biskupi lwowscy: św. Józef Bilczewski (1900-1923), Bolesław Twardowski (1923-1944) czy Eugeniusz Baziak (1944-1951), ale także niezłomni kapłani, prześladowani przez władze sowieckie, które utrudniały lub zakazywały im działalności religijno-oświatowej. Większość księży stała się ofiarą represji ze strony NKWD i opuściła Związek Sowiecki. Liczni duchowni zostali zesłani do łagrów ${ }^{10}$. Należy więc przypomnieć tych kapłanów archidiecezji lwowskiej, któ-

J. Tokarski, Ilustrowany przewodnik po zabytkach kultury na Ukrainie, t. 1, Warszawa 2000, s. 8586.

Kościół Matki Bożej Śnieżnej - najstarszy katolicki kościół Lwowa wybudowany przez mieszczan niemieckich w pierwszej połowie XIV wieku. Początkowo pełnił funkcję świątyni parafialnej dla miasta. Przy kościele bp Wacław Hieronim Sierakowski ufundował i erygował w 1772 r. kolegiatę, skasowaną w 1785 r. Po śmierci proboszcza ks. Jana Piwińskiego (1872-1949), w 1950 r. parafia przestała istnieć. Świątynię przeznaczono na magazyn, a następnie na muzeum fotografii. W połowie lat 90. XX wieku kościół przekazano ukraińskiej Cerkwi greckokatolickiej i zmieniono jego wezwanie na Matki Bożej Nieustającej Pomocy. Duszpasterstwo prowadzą redemptoryści. Ołtarze przystosowano do kultu wschodniego, a przed ołtarzem głównym ustawiono ikonostas. Tamże, s. 73-74; Lwów. Przewodnik dla zwiedzających miasto, oprac. A. Medyński, Lwów 1937.

${ }^{9}$ S.S. Nicieja, Cmentarz Eyczakowski we Lwowie w latach 1786-1986, Wrocław 1988.

${ }^{10}$ Dramatycznie przedstawiała się liczba duchowieństwa rzymskokatolickiego na terenie archidiecezji lwowskiej. Z 805 kapłanów pełniących posługę duszpasterską w 1939 r., po II wojnie światowej pozostało ich zaledwie 22, a w 1984 r. - 6: o. Rafał Kiernicki OFM Conv. (1912-1995), 
rzy po 1945 r. nie wyjechali do Polski i pozostali na ziemi swoich praojców, aby służyć miejscowym wiernym.

\section{a) Promotor kultu Bożego Miłosierdzia - ks. Karol Jastrzębski}

Pierwszym powojennym proboszczem (1946-1948) katedry pw. Wniebowzięcia Najświętszej Maryi Panny we Lwowie był ks. kanonik Karol Jastrzębski11. Urodził się on w 1882 r. w Tarnopolu, gdzie też ukończył szkołę powszechną i gimnazjum wyższe. W 1902 r. wstąpił do seminarium duchownego we Lwowie, a studia filozoficzno-teologiczne odbył na Uniwersytecie Jana Kazimierza. Po ukończeniu II roku studiów został skierowany na dalsze studia na Wydziale Teologicznym Uniwersytetu w Innsbrucku. Nie uzyskał jednak stopnia naukowego doktora z powodu negatywnego wyniku egzaminu. W 1906 r. przyjął święcenia kapłańskie. Pracował jako wikariusz i katecheta w Brzeżanach, Brodach i Stanisławowie. Od września 1912 r. objął obowiązki nauczyciela religii w dokształcającej zawodowo Szkole Żeńskiej im. H. Sienkiewicza, o takim samym profilu w Szkole Męskiej im. św. Marii Magdaleny we Lwowie oraz kapelana sióstr karmelitanek przy ulicy Czarnieckiego ${ }^{12}$.

Po II wojnie światowej był jednym z sześciu księży łacińskich pracujących na terenie Lwowa. Przez dwa lata pełnił obowiązki administratora parafii katedralnej. Po objęciu w 1948 r. przez o. Rafała Kiernickiego probostwa w katedrze ks. K. Jastrzębski poświęcił się pracy duszpasterskiej w parafii katedralnej. Jako proboszcz parafii w latach 1946-1948 organizował życie religijne wiernych, liturgię kościelną i szafarstwo sakramentów świętych. Angażował się również w działalności stołówki dla ubogich, która istniała przy parafii katedralnej. Po zaostrzeniu przez władze komunistyczne w 1949 r. polityki religijnej, zabraniającej prowadzenia działalności duszpasterskiej wśród dzieci i młodzieży oraz udzielania im sakramentów, ks. K. Jastrzębski skupił się na pracy wśród starszych wiernych, których odwiedzał w domach z posługą sakramentalną. Największą jego zasługą było wprowadzenie i propagowanie w katedrze lwowskiej nabożeństwa do Bożego Miłosierdzia. Stało się to jeszcze przed jego oficjalnym zatwierdzeniem w Kościele katolickim ${ }^{13}$. Ks. K. Jastrzębski wprowadził praktykę odprawiania nowen-

ks. Ludwik Kamilewski (1946-2019), ks. Kazimierz Mączyński (1928-1996), ks. Marcjan Trofimiak (ur. 1947), bp Jan Cieński (1905-1992), ks. Augustyn Mednis (1927-2007). J. Wołczański, Między zagłada a przetrwaniem, Kraków 2005, s. 10.

${ }^{11}$ Zob. M. Muzyka, Ks. Karol Jastrzębski 1882-1966. Katecheta, duszpasterz, promotor kultu Bożego Miłosierdzia w Archidiecezji Lwowskiej, Lwów-Kraków 2017; Z. Sokolnicka-Izdebska, Historia Kościoła we Lwowie od 1939 roku. Cz. 1, „Cracovia Leopolis”, (1996) R. 2, nr 2(6), s. 15.

${ }_{12}$ J. Wołczański, Katalog grobów duchowieństwa i sióstr zakonnych obrzadku łacińskiego i greckokatolickiego na Cmentarzu Janowskim we Lwowie, „Nasza Przeszłość”, 88 (1997) s. 266.

${ }^{13}$ Faustyna Kowalska (1905-1938) - święta ze Zgromadzenia Sióstr Matki Bożej Miłosierdzia, mistyczka, propagatorka kultu Miłosierdzia Bożego. W 1925 r. wstąpiła do zgromadzenia. Prywatne objawienia s. Faustyny rozpoczęły się 22 lutego 1931 r. w Płocku, a Jezus polecił jej namalować jego obraz z podpisem „Jezu ufam Tobie”. Taki obraz został namalowany w 1934 r. w Wilnie. Kolejne polecenie Jezusa dotyczyło ustanowienia liturgicznego święta Miłosierdzia Bożego w 1. niedzielę po Wielkanocy. W 1935 r. Jezus przekazał s. Faustynie treść „Koronki do Bożego Miłosier- 
ny w kościele katedralnym. W każdy czwartek po sprawowanej Mszy św. o Najświętszym Sakramencie była odczytywana modlitwa do Bożego Miłosierdzia, po której odbywała się procesja z Najświętszym Sakramentem wewnątrz świątyni. Nabożeństwo to jest praktykowane w katedrze lwowskiej do dziśs ${ }^{14}$.

Zamiłowanie do kultu Bożego Miłosierdzia narodziło się u ks. K. Jastrzębskiego podczas pobytu w Wilnie, gdzie przed II wojną światową spotkał się z s. Faustyną Kowalską. W czasach komunistycznych nabożeństwo to cieszyło się wśród wiernych wielką popularnością, a na czwartkowych nowennach w katedrze gromadziło się ok. 1500 wiernych $^{15}$. Duchowny ten stał się promotorem kultu Bożego Miłosierdzia w kościele lwowskim ${ }^{16}$.

W lipcu 1955 r. ks. K. Jastrzębski został jedynym kapłanem łacińskim we Lwowie $^{17}$. Ksiądz Ignacy Chwirut ${ }^{18}$ z kościoła św. Antoniego przebywał na urlopie w Karpatach, a o. Rafał Kiernicki w szpitalu. Dnia 26 sierpnia 1956 r. ks. Karol obchodził złoty jubileusz kapłaństwa. Kaznodzieja jubileuszu, jezuita ze Szczerca o. Ludwik Seweryn ${ }^{19}$ w swoim kazaniu podnosił wielkie zasługi jubilata,

dzia", a w 1937 r. tzw. godzinę miłosierdzia, czyli modlitwę w godzinie jego konania - o trzeciej po południu. W 1993 r. została ogłoszona błogosławioną, a 30 kwietnia 2000 r. kanonizowana. E. Siepak, Kowalska Faustyna. 1. Życie, 2. Objawienia prywatne, w: EK, t. 9, red. A. Szostek, Lublin 2002, kol. 1085.

${ }^{14}$ Sokolnicka-Izdebska, Historia Kościoła we Lwowie, Cz. 1, s. 16.

${ }^{15}$ Relacja ks. Ludwika Kamilewskiego, Łuck 9 IX 2019 r. (zb. wł. autora).

${ }^{16}$ Relacja Janiny Zamojskiej, Lwów 15 XII 2007 r. (zb. wł. autora).

${ }^{17}$ Z. Sokolnicka-Izdebska, Historia Kościoła we Lwowie od 1939 roku. Cz. 2, „Cracovia Leopolis", (1996) R. 2, nr 3(7), s. 14.

18 Ignacy Chwirut (1887-1973) - kapłan archidiecezji lwowskiej, kanonik gremialny Kapituły Metropolitalnej we Lwowie. Studia filozoficzno-teologiczne odbył w latach 1908-1912 w seminarium duchownym we Lwowie, gdzie przyjął święcenia kapłańskie z rąk abpa Józefa Bilczewskiego. Jako neoprezbiter podjął pracę w parafii Zaleszczyki. W 1913 r. został sekretarzem abpa J. Bilczewskiego, do jego śmierci w 1923 r. Tę samą funkcję podjął u boku abpa Bolesława Twardowskiego w latach 1923-1929. Był dyrektorem spółki wydawniczej „Biblioteka Religijna”. Dnia 4 stycznia 1945 r. został aresztowany przez NKWD pod zarzutem wydawania czasopisma „Gazeta Kościelna” i drukowania w nim artykułów antysowieckich oraz agitacji ekspatriacyjnej. Skazany 26 grudnia 1946 r. w Moskwie na 5 lat łagrów i pozbawienie praw obywatelskich. Więzienie opuścił na początku stycznia 1950 r. i przybył do Lwowa. Dopiero po zameldowaniu się w budynku parafii św. Antoniego, w maju 1953 r. otrzymał zezwolenie na sprawowanie kultu i probostwo w tej parafii. Według opinii władz sowieckich „Aktywności nie przejawiał, kazań nie wygłaszał”. Ze względu na stan zdrowia w czerwcu 1969 r. przekazał obowiązki proboszcza ks. Kazimierzowi Mączyńskiemu, przybyłemu do Lwowa z diecezji ryskiej. Zmarł po długiej chorobie w 1973 r. i został pochowany na Cmentarzu Janowskim. P. Olechowski, Między ottarzem a gabinetem partyjnym. Kościót rzymskokatolicki w sowieckim Lwowie w latach 1953-1959 w świetle raportów petnomocnika Rady ds. Kultów Religijnych w obwodzie lwowskim, „Pamięć i Sprawiedliwość”, 16 (2017) nr 1 (29), s. 182186; Sanktuarium Świętego Antoniego, https://antoni.lviv.ua/pl/ksieza-w-nieprzerwanej-sluzbie/ (dostęp: 26.02.2021).

${ }^{19}$ Seweryn Ludwik (1906-1970) - jezuita. Do zakonu wstąpił w 1922 r. Filozofię studiował w Krakowie i Engenhoven w Belgii, teologię w Lublinie, gdzie w 1934 r. przyjął święcenia kapłańskie. Do wojny pracował w męskiej Bursie ks. Mieczysława Kuznowica w Krakowie. Podczas II wojny światowej pracował w Kołomyi. W 1945 r. został uwięziony i zesłany na Syberię, a następ- 
w tym jego pracę katechetyczną. W szczególny sposób podkreślił zapoczątkowanie przez niego nabożeństwa do Miłosierdzia Bożego, a swoje wystąpienie zakończył słowami: „,gdyby nie Miłosierdzie Boże, dawno by nas tu nie było"20.

Ważną cechą ks. K. Jastrzębskiego była jego otwartość na potrzeby innych. Stale wspierał biednych i rodziny wielodzietne. Jego praca duszpasterska i katechetyczna odznaczała się starannością i dokładnością. Był powszechnie poważany i lubiany za godną postawę, pełną kultury i właściwego stosunku do drugiego człowieka, nawet jeśli ktoś przejawiał pewną srogość. Miał zasadę, że spotykając urzędnika już mu znanego, pierwszy zdejmował kapelusz i pozdrawiał. Mówiono o nim, że był dobrym kapłanem, gdyż właściwie dbał o pobożność wśród ludzi i troszczył się o upowszechnienie nabożeństwa do Bożego Miłosierdzia. A były to czasy, w których modlono do Pana Boga o jak najwięcej miłosierdzia ${ }^{21}$. Z jednego ze wspomnień o ks. K. Jastrzębskim wyłania się postać z wyglądu niepozorna i niskiego wzrostu, ale niesłychanie towarzyska, wykonująca śpiewy liturgiczne na wysokim poziomie.

W pamięci niektórych zapisał się jako inteligentny kapłan, który potrafił wzbudzić do siebie zaufanie i szacunek, zarówno wśród wiernych, jak i urzędników lokalnych władz państwowych. Jego popularność w mieście była do tego stopnia duża, że pewnego dnia, gdy szedł chodnikiem, motorniczy zatrzymał tramwaj i zaprosił ks. K. Jastrzębskiego do jazdy. Duchowny wyznawał zasadę, że należy zawsze być wiernym swoim przekonaniom wobec wszystkich, nawet wrogów religii. Swoje poglądy należy wyrażać spokojnie, wykorzystując w argumentacji porównania z życia codziennego, a nawet żart czy dowcip. Jako kapłan na różne możliwe sposoby zabiegał o pozyskiwanie ludzi dla wiary, Boga i Kościoła ${ }^{22}$.

Warto podkreślić, że ks. K. Jastrzębski w czasie wykonywania posługi duszpasterskiej we Lwowie nigdy nie został sądownie ukarany za swoją działalność. Nie znaczy to jednak, że nie był wzywany przez NKWD na przesłuchania i do urzędu pełnomocnika Rady ds. kultów religijnych w obwodzie lwowskim. Gdy

nie do Kazachstanu. Po zwolnieniu w 1955 r. osiadł w Szczercu koło Lwowa, gdzie był proboszczem do śmierci. Pomagał w pracy duszpasterskiej w kościołach lwowskich i w okolicy. Zmarł we Lwowie. Jest autorem broszury Prawda na ciężkie czasy wydanej przez księży jezuitów w Krakowie. Seweryn Ludwik, w: Encyklopedia wiedzy o jezuitach na ziemiach Polski i Litwy 1564-1995, red. L. Grzebień, Kraków 1996, s. 612.

${ }^{20}$ Sokolnicka-Izdebska, Historia Kościoła we Lwowie, Cz. 2, s. 14.

${ }^{21}$ Relacja Janiny Zamojskiej.

${ }^{22}$ Ks. K. Jastrzębski utrzymywał znajomość ze znaną ukraińską śpiewaczką (sopran) operową Salomeą Kruszelnicką (1873-1952), córką księdza greckokatolickiego, którego znał wcześniej. Debiutowała w 1892 r. w operze we Lwowie, występowała w Operze Warszawskiej 1898-1902 i Operze Paryskiej i w Buenos Aires. W 1910 r. poślubiła markiza Cesarego Riccioniego. Występowała na scenie mediolańskiej La Scali, gdzie była pierwszą odtwórczynią ról Salome i Elektry w operach R. Straussa. W 1920 r., będąc u szczytu sławy, zostawiła na zawsze arenę operową i poświęciła resztę życia wykonawstwu muzyki kameralnej. W sierpniu 1939 r. zamieszkała na stałe we Lwowie, gdzie otrzymała tytuł profesorski i prowadziła klasę wokalną w Lwowskim Konserwatorium. Ze względu na jej obojętność religijną ks. K. Jastrzębski chciał zbliżyć ją do Kościoła i wiary, ale bez skutku. Martwił się, że córka duchownego zachowuje obojętną, a nawet lekceważącą postawę wobec religii. Relacja J. Zamojskiej, Lwów 15 XII 2007 r. (zb. wł. autora). 
udawał się na nie, zawsze szedł w towarzystwie przynajmniej dwóch osób, nawet starszych pań. Uważał, że wywoływało to pewne wrażenie na lokalnych urzędnikach, niekiedy nawet śmieszne: „on staruszek i dwie staruszki koło niego”. W ich trakcie otrzymywał standardowe pytania na tematy „kościelne”, na które odpowiadał inteligentnie i żartobliwie, np. jakie są jego stosunki ze Stolicą Apostolską? Wówczas odpowiadał: „A cóż Stolica Apostolska o mnie wie, że ja tu jestem? Nas jest dużo, a ja specjalnie niczym się nie odznaczałem”. W czasie tych „spotkań” konsekwentnie nie udzielał obszernych odpowiedzi na stawiane pytania, z tego powodu traktowany był jako osoba apolityczna i fanatyk religijny, niestwarzający zagrożenia dla władzy komunistycznej. Do pracujących urzędników zwracał się „panie ministrze”, kłaniał się napotkanym funkcjonariuszom, nie wdawał się w niepotrzebne dyskusje, wykluczając ostrzejsze polemiki czy kłótnie, a rozmowę starał się prowadzić w luźniejszej atmosferze, odpowiadając nawet $\mathrm{z}$ humorem na trudniejsze pytania. W ten sposób urzędnicy przyjmując pochlebstwa księdza, nabierali do niego pewnego dystansu, a ostatecznie ze względu na jego starszy wiek, tracili zainteresowanie osobą duchownego ${ }^{23}$.

W ostatnich latach swej posługi pastoralnej w katedrze ks. K. Jastrzębski ze względów zdrowotnych ograniczał się wyłącznie do odprawiania mszy św. i posługi w konfesjonale ${ }^{24}$. Od 1965 r. nie uczestniczył już w życiu parafialnym katedry, mszę św. zaś odprawiał w mieszkaniu. Zmarł 7 stycznia 1966 r. we Lwowie. Pochowany został w grobowcu rodzinnym na Cmentarzu Janowskim. Ceremonii pogrzebowej w dniu 11 stycznia przewodniczył ks. Zygmunt Hałuniewicz. W kazaniu podkreślił zasługi ks. K. Jastrzębskiego w duszpasterstwie parafialnym, jego wierność powołaniu kapłańskiemu i służbie wiernym według osobistej maksymy: „Bogu służę"25.

\section{b) Krzewiciel kultu Bożego Miłosierdzia - ks. Stanisław Płoszyński}

W posłudze duszpasterskiej ks. K. Jastrzębskiemu pomagał ks. Stanisław Płoszyński ${ }^{26} . Z$ powojennych wspomnień o tym duchownym można dowiedzieć się, że był kapłanem o wielkiej gorliwości. W pracy duszpasterskiej i posłudze pastoralnej był bardzo wymagający, ale o dobrym sercu. Prowadził naukę religii dla

${ }^{23}$ Wołczański, Katalog grobów duchowieństwa i sióstr zakonnych, s. 266; Relacja Janiny Zamojskiej.

${ }^{24}$ Relacja Janiny Zamojskiej.

${ }^{25}$ Z. Sokolnicka-Izdebska, Historia Kościoła we Lwowie od 1939 roku, Cz. 3, „Cracovia Leopolis", (1996) R. 2, nr 4(8), s. 19.

${ }^{26}$ Stanisław Płoszyński (1914-1949) - kapłan archidiecezji lwowskiej. Święcenia kapłańskie przyjął w 1939 r. we Lwowie. W czasie II wojny światowej pracował jako wikariusz w parafiach w Śniatynie i Gołogórach. W lutym 1944 r. został aresztowany przez NKWD, lecz w tym samym miesiącu został zwolniony i od 25 września 1944 r. pracował jako administrator parafii Powitno, dojeżdżając także do parafii Białogiria. W latach 1945-1949 pracował w katedrze lwowskiej jako wikary. Skupiał się głównie na pracy z młodzieżą, współpracując w tym zakresie z ks. Janem Olszańskim, wówczas duszpasterzem lwowskiej Parafii Matki Bożej Śnieżnej. Zmarł we Lwowie i został pochowany na Cmentarzu Janowskim w grobowcu jezuitów. Płoszyński Stanisław, w: R.Dzwonkowski, Leksykon duchowieństwa polskiego represjonowanego w ZSRS 1939-1988, Lublin 2003, s. 488-489. 
dzieci, które przygotowywał do Pierwszej Komunii Świętej oraz organizował dla nich uroczyste przyjęcie tego sakramentu, a przedtem spowiedzi. Nazywany był apostołem młodzieży, ponieważ prowadził spotkania katechetyczne w czynnych kościołach Lwowa: katedrze, św. Antoniego, św. Marii Magdaleny i Matki Bożej Śnieżnej. Jego zaangażowanie w katedrze lwowskiej, uznane w 1948 r. przez pełnomocnika ds. religii jako niekościelne, spowodowało likwidację niedzielnych spotkań religijnych z młodzieżą oraz zamknięcie kuchni dla ubogich, ponieważ władze komunistyczne uważały, że służyła ona werbowaniu wierzących ${ }^{27}$.

Nie sposób pominąć starań ks. S. Płoszyńskiego na polu wychowania patriotycznego. Wkładał on dużo wysiłku, aby dzieci, młodzież i starsi o polskich korzeniach poznawali i kultywowali zwyczaje oraz tradycję narodu polskiego. W związku z tym uważał, że w liturgii powinien być używany wyłącznie język polski, co było również nakazane przez władze sowieckie. Odnosiło się to głównie do głoszenia kazań, gdyż liturgia mszy św. była sprawowana po łacinie ${ }^{28}$.

W czasach sowieckich do katedry łacińskiej przybywali także wierni Cerkwi greckokatolickiej, którzy po zamknięciu przez władze ich świątyń nie chcieli przejść na prawosławie. Ks. S. Płoszyński w miarę możliwości prowadził duszpasterstwo wśród Ukraińców. Grekokatolicy gromadzili się w domach lub zbierali się w katedrze jako grupy śpiewacze, aby modlić się w języku ukraińskim. Jednak ks. S. Płoszyński zdecydowanie się temu sprzeciwiał, ponieważ używanie innego języka w katedrze, oprócz polskiego, groziło zamknięciem świątyni. $Z$ tego też powodu ogłosił w czasie kazania zakaz modlenia się po ukraińsku. Trzeba w tym miejscu zaznaczyć, że w latach powojennych nastroje w polskich środowiskach były antyukraińskie. Wpływała na to żywa pamięć o mordach Polaków na Wołyniu i Podolu, co rzutowało na wzajemne relacje Polaków i Ukraińców, także na płaszczyźnie religijnej. Pewna część rzymskich katolików przyjmowała ze zrozumieniem korzystanie grekokatolików z ich świątyń i postawę posługujących kapłanów. Z upływem lat atmosfera stawała się bardziej otwarta i poprawna ${ }^{29}$.

Ks. S. Płoszyński zmarł 25 marca 1949 r. Jego pogrzeb był wielką religijną manifestacją katolickiej ludności miasta, liczącą ponad dziesięć tysięcy wiernych, w tym także grekokatolików. Kondukt żałobny z katedry na Cmentarz Janowski był tak duży, że doprowadził do wstrzymania ruchu tramwajów miejskich. Była to jedna $\mathrm{z}$ ostatnich tak licznych manifestacji Polaków we Lwowie po II wojnie światowej ${ }^{30}$.

\section{c) Birytualista lwowski - ksiądz Zygmunt Hałuniewicz}

Kolejną wielką postacią lwowskiego kościoła był ks. prałat Zygmunt Hałuniewicz. Urodził się on 27 czerwca 1889 r. w Rohatynie, w województwie stanisła-

27 Tamże.

${ }^{28}$ Relacja Janiny Zamojskiej.

${ }^{29}$ Tamże.

${ }^{30}$ W. Osadczy, Kościól wyznawców. Kapłani archidiecezji lwowskiej obrządku łacińskiego w latach 1945-1991, w: Prorocy Europy Środko-Wschodniej XX wieku, red. S. C. Napiórkowski OFMConv, Lublin 2009, s. 187; Wołczański, Katalog grobów duchowieństwa i sióstr zakonnych, s. 258 . 
wowskim (obecnie obwód Iwano-Frankowski). Po maturze wstąpił do seminarium duchownego we Lwowie, będąc jednocześnie studentem Wydziału Teologicznego na Uniwersytecie Jana Kazimierza. Święcenia kapłańskie przyjął 30 czerwca 1912 r. z rąk abpa Józefa Bilczewskiego ${ }^{31}$.

Jako neoprezbiter skierowany został do parafii w Pieniakach, gdzie pracował jako wikariusz i katecheta. W 1916 r. przejął równorzędne obowiązki w parafii św. Antoniego we Lwowie, a jednocześnie był protokolantem w Kurii Metropolitalnej we Lwowie. W 1919 r. został przeniesiony do katedry lwowskiej, gdzie podjął obowiązki wikariusza i notariusza kurialnego. W 1921 r. został mianowany jej kanclerzem i na tym stanowisku pozostał do 1945 r. Był współpracownikiem arcybiskupów: Józefa Bilczewskiego, Bolesława Twardowskiego i Eugeniusza Baziaka. W kurii pełnił funkcje referendarza, sędziego synodalnego, egzaminatora prosynodalnego. Otrzymał godność kanonika gremialnego Kapituły Metropolitalnej Lwowskiej ${ }^{32}$.

Po aneksji wschodnich województw Rzeczpospolitej we wrześniu 1939 r. przez Związek Sowiecki ks. Z. Hałuniewicz, był represjonowany przez władze komunistyczne. W dniu 26 listopada 1945 r. został aresztowany pod zarzutem współpracy z Gestapo i prowadzenie aktywnej działalności antysowieckiej. Oskarżono go też o stworzenie antysowieckiej nacjonalistycznej organizacji „Miecz i Krzyż” ${ }^{33}$ oraz przechowywanie antysowieckiej literatury. Dnia 19 czerwca 1946 r. został skazany na 10 lat łagrów, 5 lat pozbawienia praw cywilnych

${ }^{31}$ Józef Bilczewski (1860-1923) -metropolita lwowski. Kształcił się w Kętach, Wadowicach i Krakowie, gdzie otrzymał w 1884 r. święcenia kapłańskie. Pracował jako wikariusz w Mogile k. Krakowa. Następnie studiował w Wiedniu, Paryżu i Rzymie. Był profesorem Uniwersytetu Jana Kazimierza we Lwowie, a w 1900 r. został jego rektorem. Dnia 17 grudnia 1900 r. otrzymał nominację na metropolitę lwowskiego. Sakrę biskupią przyjął 20 stycznia 1901 r. Jako pasterz archidiecezji erygował dużo parafii, rozwijał budownictwo sakralne, prowadził działalność oświatową i charytatywną. Szczególnie przyczynił się do rozwoju kultu eucharystycznego. W 2001 r. został ogłoszony błogosławionym, a 23 października 2005 r. kanonizowany. J. Machniak, Abp Józef Bilczewski. Pasterz Kościoła Lwowskiego, Kraków 2001.

${ }^{32}$ Hałuniewicz Zygmunt, w: Dzwonkowski, Leksykon duchowieństwa polskiego, s. 253; T. Madała, Polscy księża katoliccy w więzieniach i tagrach sowieckich od 1918 roku. Materiaty do słownika biograficznego, Lublin 1996, s. 61; J. Wołczański, Kapłani męczennicy. Świadkowie wiary kościota lwowskiego ksiądz kanclerz Zygmunt Hałuniewicz (1889-1974), „Radość Wiary”, (1999) nr 3-4 (23-24), s. 17.

${ }^{33}$ W styczniu 1945 r. został aresztowany abp wileński Romuald Jałbrzykowski oraz bp łucki Adolf Szelążek. Abp E. Baziak pozostawał w tym czasie jedynym polskim biskupem sprawującym swą jurysdykcję na terenie ZSRS i w każdej chwili mógł zostać uwięziony przez NKWD. Może świadczyć o tym sprawa kanonika lwowskiego ks. Z. Hałuniewicza, który w listopadzie $1945 \mathrm{r}$. został aresztowany i oskarżony o stworzenie na polecenie emigracyjnego rządu polskiego z abpem E. Baziakiem antysowieckiej organizacji nacjonalistycznej „Miecz i Krzyż”. Była to młodzieżowa tajna formacja, jedna $\mathrm{z}$ kilkuset podobnych w Polsce, która miała charakter antysowiecki. J. Baziak, Wygnaniec, tułacz a może Ikar, Bydgoszcz 2019, s. 25; J. Wołoszyn, Podstawy antysystemowe mtodzieży w wybranych państwach socjalistycznych Europy Środkowo-Wschodniej w latach 19451956 - zarys problematyki, „Rocznik Instytutu Europy Środkowo Wschodniej”, 18 (2020) z. 4, s. 209. 
i konfiskatę mienia. Pomimo starań władz sowieckich wysunięte oskarżenia przeciwko ks. Z. Hałuniewiczowi, które były podstawą do aresztowania, nie miały mocy dowodowej ${ }^{34}$, nawet $\mathrm{w}$ opinii agentów $\mathrm{NKGB}^{35}$ Władze skonfiskowały i spaliły jego książki ${ }^{36}$ oraz polskie godło. Mieszkanie ks. Z. Hałuniewicza wraz z wyposażeniem zajął agent MGB. W 1946 r. ks. Z. Hałuniewicz został deportowany do łagru w Donbasie, gdzie pracował w kamieniołomach, a następnie do łagru w Miedwieżjegorsku, gdzie miał odbywać „leczenie”, które polegało na zwolnieniu zesłańca z pracy fizycznej. Następnie ks. Z. Hałuniewicz został odesłany do łagru Szczerbakow-7, a w 1948 r. do łagru w Miliuszyno. Został zwolniony 29 kwietnia 1955 r., a już 2 maja powrócił do Lwowa. W jednym ze wspomnień z tamtych czasów napisano: „Szczęśliwym bardzo wydarzeniem wśród fali niepowodzeń był pow rót z obozu ks. prałata Zygmunta Hałuniewicza" ${ }^{37}$. W dniu 15 lipca 1955 r. uzyskał rejestrację w parafii św. Marii Magdaleny, gdzie pracował do 22 października 1962 r., czyli do zamknięcia kościoła przez władze ${ }^{38}$.

Ks. Z. Hałuniewicz podjął pracę duszpasterską w parafii św. Marii Magdaleny po śmierci ( $\dagger 6$ listopada 1949 r.) ks. Zygmunta Truszkowskiego ${ }^{39}$. W posłudze Słowa Bożego był zawsze bardzo dobrze przygotowany, a głoszone przez niego kazania były dopracowane ${ }^{40}$. Zwracał także uwagę na potrzeby i niedostatek ludzi, którym starał się pomagać. Pracował również w katedrze lwowskiej, gdzie pomagał mającemu problemy zdrowotne ks. K. Jastrzębskiemu. Pomimo swojej niezbyt dobrej kondycji ofiarnie pełnił posługę wśród chorych i umierających, w czasie gdy o. Rafałowi Kiernickiemu władze sowieckie zakazały pełnienia funkcji dusz-

${ }^{34}$ Hałuniewicz Zygmunt, Dzwonkowski, Leksykon duchowieństwa polskiego, s. 253; Wołczański, Kapłani męczennicy. Świadkowie wiary kościoła lwowskiego, s. 17.

${ }^{35}$ Narodnyj Komissariat Gosudarstwiennoj Biezopasnosti - Ludowy Komisariat Bezpieczeństwa Państwowego (1941-1946, równolegle z NKWD; w 1946 NKWD i NKGB zostały połączone i przemianowane na MGB - Ministerstierstwo Gosudarstwiennoj Biezopasnosti SSSR (Ministerstwo Bezpieczeństwa Państwowego ZSRR).

${ }^{36} \mathrm{~W}$ protokole zaznaczono siedem pozycji o nader enigmatycznych tytułach, bez podania miejsca i roku skonfiskowanych wydań.

${ }^{37}$ Sokolnicka-Izdebska, Historia Kościoła we Lwowie, Cz. 2, s. 13.

${ }^{38}$ Hałuniewicz Zygmunt, w: Dzwonkowski, Leksykon duchowieństwa polskiego, s. 253; Madała, Polscy księża katoliccy w więzieniach i łagrach, s. 61; Sokolnicka-Izdebska, Historia Kościoła we Lwowie, Cz. 2, s. 13.

${ }^{39}$ Zygmunt Truszkowski (1876-1949) - misjonarz św. Wincentego à Paulo. Do zakonu wstąpił po studiach medycznych. Święcenia kapłańskie przyjął w 1901 r. w Krakowie. Pracował w archidiecezji lwowskiej, następnie na terenie Krakowa. W 1919 r. przeszedł do kleru diecezjalnego i podjął pracę w duszpasterstwie wojskowym. W czasie II wojny światowej był dziekanem kapelanów wojskowych we Lwowie 1943-1944. W połowie 1945 r. został aresztowany przez NKWD i skazany na 10 lat łagrów w grupowym procesie duchowieństwa we Lwowie dnia 25 lutego 1946 r. Po wykazaniu się osobistą znajomością z Leninem, który w 1914 r. pożyczył od niego pieniądze, został natychmiast zwolniony. Otrzymał wówczas rejestrację na proboszcza kościoła św. Marii Magdaleny. Tu duszpasterzował przez trzy lata. Zmarł we Lwowie i został pochowany na Cmentarzu Łyczakowskim. Truszkowski Zygmunt, w: Dzwonkowski, Leksykon duchowieństwa polskiego represjonowanego w ZSRS 1939-1988, Lublin 203, s. 601-602.

${ }^{40}$ Sokolnicka-Izdebska, Historia Kościoła, Cz. 2, s. 14. 
pasterskich w katedrze lwowskiej. W czasie tego „zawieszenia”, ks. Z. Hałuniewicz przejął obowiązki proboszcza w katedrze.

W pracy duszpasterskiej jako proboszcz kościoła św. Marii Magdaleny, a później w katedrze lwowskiej ks. Z. Hałuniewicz wraz z tamtejszymi księżmi prowadził ukryte duszpasterstwo wiernych obrządku greckokatolickiego. Sprawował dla nich posługę sakramentalną, paraliturgiczną (poświęcenia i błogosławieństwa pokarmów wielkanocnych, poświęcenia palm, obrazków, różańców) oraz zezwalał kapłanom greckokatolickim spowiadać swoich wiernych w bazylice katedralnej ${ }^{41}$.

Zsyłka i pobyt w łagrach odbiły się na jego zdrowiu. Miał kłopoty z nerkami, sercem i cukrzycą ${ }^{42}$. Zmarł 30 marca 1974 r. na zapalenie płuc. Pogrzeb odbył się 2 kwietnia. Mszy pogrzebowej przewodniczył ks. Jan Cieński ${ }^{43}$ ze Złoczowa, biskup in pectore. Swego duszpasterza żegnali również katolicy dwóch obrządków. Grekokatolicy po skończonych egzekwiach odśpiewali panichidę ${ }^{44}$. Ks. Z. Hałuniewicz został pochowany na Cmentarzu Janowskim, w grobowcu jezuitów, obok ks. Ignacego Chwieruta i o. Ludwika Seweryna, świadków najtrudniejszych czasów dla Kościoła i duszpasterzy lwowskich. Po śmierci ks. Z. Hałuniewicza w katedrze lwowskiej pozostał tylko jeden kapłan, o. Rafał Kiernicki ${ }^{45}$.

Jeszcze za swojego życia, ks. Z. Hałuniewicz podjął staranie o rehabilitację sądową. W dniu 4 kwietnia 1955 r. urzędnik KGB we Lwowie uznał, że był on bezzasadnie oskarżony z artykułów 54-11. Jednak pełna rehabilitacja duchownego nastąpiła dopiero 28 czerwca 1993 r. - 19 lat po śmierci.

${ }^{41}$ Будз, Украӥнська Греко-Католицька Церква, s. 126; Sokolnicka-Izdebska, Historia Kościoła we Lwowie, Cz. 3, s. 22; Wołczański, Kapłani męczennicy. Świadkowie wiary kościoła lwowskiego, s. 19.

${ }^{42}$ Z. Sokolnicka-Izdebska, Historia Kościoła we Lwowie od 1939 roku, Cz. 4, „Cracovia Leopolis" (1997) R. 3, nr 1(9), s. 13.

${ }^{43}$ Jan Cieński (1905-1992) - proboszcz w Złoczowie, biskup in pectore. W 1928 r. ukończył Akademię Rolniczą w Dublanach i zapisał się na studia prawnicze na Uniwersytecie Jana Kazimierza we Lwowie, które przerwał w 1933 r. i wstąpił do miejscowego seminarium duchownego. Święcenia kapłańskie przyjął 26 czerwca 1938 r. we Lwowie. Jako neoprezbiter został wikariuszem w Złoczowie, od 26 listopada 1945 r. aż do śmierci administratorem i proboszczem tej parafii. W czasie II wojny światowej ukrywał i ratował Żydów i polskich mieszkańców Złoczowa przed masowymi rzeziami; był kapelanem miejscowego inspektoratu Armii Krajowej. Po wojnie pozostał w rodzinnym Złoczowie, pełniąc posługę kapłańską, mimo szykan. Dzięki zabiegom Stefana kard. Wyszyńskiego, ks. J. Cieński został tajnym biskupem (in pectore) w 1962 r. Dopiero 30 września 1967 r. został konsekrowany potajemnie w Gnieźnie przez Prymasa Tysiąclecia. Biskup J. Cieński wyświęcił potajemnie kilku kapłanów greckokatolickich i prawdopodobnie dwóch rzymskokatolickich. Zmarł w Złoczowie 26 grudnia 1992 r. i został pochowany na parafialnym cmentarzu.

${ }^{44}$ Panichida - liturgiczne nabożeństwo za zmarłych w Kościołach wschodnich. Składa się z psalmów, ektenii (modlitwie wiernych), hymnów i modlitw wzorowanych na schemacie jutrzni z dodaniem kontakionu za zmarłych i wersu wieczna pamięć. Podczas odprawiania panachidy na stoliku stawia się zapalone świece, a pod koniec nabożeństwa zapalają świece także wierni oraz jest błogosławione przez kapłana koliwo - pszenica z miodem, które następnie jest spożywane. H. Paprocki, Panichida, w: EK, t. 14, red. E. Gigilewicz, Lublin 2010, kol. 1214.

${ }^{45}$ Sokolnicka-Izdebska, Historia Kościoła we Lwowie, Cz. 4, s. 13. 


\section{d) Męczennik konfesjonału - ojciec Rafał Władysław Kiernicki}

Władysław Kiernicki urodził sie 3 maja 1912 r. w Kułaczkowcach koło Kołomyi. W 1930 r. wstąpił do franciszkanów konwentualnych, przyjmując imię Rafał. Nowicjat odbył w Łagiewnikach koło Łodzi. W dnia 4 października 1934 r. złożył śluby wieczyste ${ }^{46}$. Święcenia kapłańskie przyjął 1939 r. Jako neoprezbiter podjął obowiązki spowiednika sióstr zakonnych, a od 1940 r. był także kuratorem koła lwowskiego „Juventus Christiana”" ${ }^{47}$. Wykładał również na tajnych kompletach gimnazjalnych. W czasie II wojny światowej należał do konspiracji wojskowej, pseudonim „Dziunio”. Był szefem V/K Inspektoratu Lwów - miasto ZWZ -AK, a od marca 1944 r. szefem Wydziału Łączności Konspiracyjnej V/K Lwów. W dniu 31 lipca 1944 r. został aresztowany we Lwowie i zesłany do obozu w Charkowie ${ }^{48}$, gdzie przebywał od września 1944 do marca 1945 r. W obozie brał aktywny udział w wydawaniu konspiracyjnej, ręcznie pisanej gazetki „Semper Fidelis" 49.

W marcu 1945 r. został skierowany do obozu w Diagilewie-Riazań, w czerwcu 1947 r. został przeniesiony do obozu jenieckiego w Riazaniu, a następnie do obozu w Czerepowcu (obwód wołogodzki). Od początku 1948 r. był internowany w obozie jenieckim w Griazowcu. W obozach o. R. Kiernicki prowadził aktywną konspiracyjną działalność duszpasterską wśród więźniów różnych narodowości. Zdarzało się, że w niektórych łagrach władze pozwalały kapłanom na posługę duszpasterską. Wówczas zakonnik udzielał sakramentów oraz organizował kursy wiedzy religijnej ${ }^{50}$.

Na początku kwietnia 1948 r. o. R. Kiernicki został zwolniony z obozu jenieckiego i powrócił do Lwowa. Podjął wówczas pracę duszpasterską w katedrze, a w następnym roku uzyskał rejestrację na jej proboszcza ${ }^{51}$. Był bardzo energiczny,

${ }^{46}$ M.B. Kuczyńska, „Nazywano Ojca Szaleńcem Bożym”. Bp. Władysław Rafał Kiernicki OFMConv. Duszpasterz i zesłaniec (1912-1995), „Zesłaniec”, 64 (2015) s. 26.

${ }^{47}$ Iuventus Christiana - stowarzyszenie katolickiej młodzieży akademickiej. Powstało w $1921 \mathrm{r}$. w Warszawie. Zakładało głębsze poznanie prawd wiary i zastosowanie ich w życiu osobistym i społecznym poprzez spotkania w grupach koedukacyjnych pod kierunkiem kapłana, a od 1926 r. także osoby świeckiej. Podstawą samokształcenia jego członków stanowiło Pismo Święte komentowane podczas spotkań przez wszystkich uczestników. Organem stowarzyszenia był periodyk „Iuventus Christiana”. W 1939 r. instytucja ta była najliczniejszą akademicką organizacją katolicką. Po wybuchu wojny wznowiła działalność od grudnia 1939 r. Po aresztowaniach w 1940 r. stowarzyszenie rozwiązano. Odtąd czynnikiem łączącym jego członków była powołana Rada Ideowa, która wznowiła działalność kół konspiracyjnych. Na podstawie dekretu państwowego z 25 sierpnia 1949 r. organizacja przestała istnieć. S. Gajewski, Iuventus Chistiana, Juventus, w: EK, t. 7, red. J. Duchniewski i in., Lublin 1997, kol. 564-565.

${ }^{48}$ Kuczyńska, ,, Nazywano Ojca Szaleńcem Bożym, s. 30.

${ }^{49}$ Kiernicki Władysław, w: R. Dzwonkowski, Leksykon duchowieństwa polskiego represjonowanego w ZSRR 1939-1988, Lublin 2003, s. 318.

${ }^{50}$ Tamże.

${ }^{51}$ Osadczy, Kościót wyznawców, s. 191. 
o wielkim zapale i zaangażowaniu duszpasterskim. Często mówił o sobie, że cierpi na ,chorobę aktywizmu”. Zdarzało się, że w przeciągu jednego dnia poprowadził 5 pogrzebów lub wyspowiadał ponad 200 penitentów czy też odprawił kilka mszy św. ${ }^{52}$

Harmonogram powszedniego dnia o. R. Kiernickiego można poznać ze świadectw na temat jego posługi:

Przed 6 rano już był w konfesjonale; o 7.30 Msza Święta z krótkim kazaniem; po Mszy Świętej załatwienie spraw kancelaryjnych w zakrystii katedry; po załatwianiu spraw znów konfesjonał z udzielaniem Komunii Świętej co pół godziny, aż do godziny $12.00^{53}$; następnie odwiedziny chorych (przemierzał nierzadko setki kilometrów, np. Łuck, Równe, Stanisławów); pogrzeby, spotkania organizacyjne z najbliższymi współpracownikami, ministrantami; o 17.00 godzinie zajmował miejsce w konfesjonale aż do nabożeństwa wieczornego o godz. $19.00^{54}$.

Bardzo często zasypiał $\mathrm{w}$ fotelu w zakrystii, taki był zmęczony... W tym wszystkim nikt nie umiał wyjaśnić, skąd u tak schorowanego człowieka było tyle sił do tak ofiarnej służby. Bowiem przeszedł dwie operacje nerek, trzy operacje na skręt jelit, trzy operacje na żylaki oraz był chory na serce ${ }^{55}$.

W 1958 r. o. R. Kiernicki został pozbawiony przez władzę sowiecką prawa do wykonywania czynności duszpasterskich. W tym czasie oficjalnie pracował jako dozorca w Parku Stryjskim we Lwowie oraz jako nocny stróż w sanatorium na Hołosku. W wolnych chwilach spełniał w sposób konspiracyjny posługę duszpasterską, głównie sakramentalną, niejednokrotnie narażając się na konsekwencje prawne. Dopiero po siedmiu latach - w 1965 r. powrócił do pracy duszpasterskiej ${ }^{56}$, otrzymawszy tzw. sprawkę ,służytiela kulta”.

W liście do prowincjała w 1961 r. napisał:

Pracuję dalej po nocach. Czuję się pożytecznym i potrzebnym dla ludzi. To mi daje zadowolenie. Ze zdrowiem wszystko w porządku. Czasem tęsknie za spokojem, ale na to trzeba było się urodzić w innej epoce. Żyję z dnia na dzień nie wiedząc, co przyniesie jutro. Nie narzekam nigdy. Przeciwnie, warunki te uważam za romantykę swego życia ${ }^{57}$.

O. Rafała postrzegano jako więźnia konfesjonału ${ }^{58}$, której to posłudze poświęcał się bez reszty ${ }^{59}$. Dzięki temu jego wierni odzyskiwali możliwość życia w łasce

${ }^{52}$ M. Skowyra, Jubileusz sześćdziesięciolecia śmierci arcybiskupa metropolity Bolestawa Twardowskiego i dziewiąta rocznica śmierci bpa Rafała Kiernickiego, „Radość Wiary”, (2004) nr 7 (43), s. 7.

${ }^{53}$ Czasami udzielano do 1000 Komunii Świętych dziennie. Por. J. Krętosz, Katedra obrzadku tacińskiego we Lwowie i jej proboszcz o. Rafat Kiernicki OFMConv w latach 1948-1991, Katowice 2003, s. 74.

${ }^{54}$ Relacja ks. Ludwika Kamilewskiego.

${ }_{55}^{55}$ J.M. Paluch, Ojciec Rafat, „Cracovia Leopolis”, 7 (2001) nr 3 (27), s. 12.

${ }^{56}$ Kuczyńska, ,Nazywano Ojca Szaleńcem Bożym”, s. 33.

${ }^{57}$ Skowyra, Jubileusz sześćdziesięciolecia śmierci arcybiskupa metropolity Bolesława Twardowskiego, s. 7.

${ }^{58}$ Osadczy, Kościót wyznawców, s. 197.

${ }^{59}$ Relacja ks. Ludwika Kamilewskiego. 
Bożej, a poprzez rady i pouczenia nabywali właściwej równowagi ducha ${ }^{60}$. Zakonnik był niezmordowanym szafarzem sakramentu chorych. Systematycznie odwiedzał chorych i starszych przed pierwszym piątkiem miesiąca według listy adresowej ze Lwowa i okolic, nie zważając na odległośćc ${ }^{6}$. Jako jedyny kapłan we Lwowie odwiedzał pacjentów w szpitalach ${ }^{62}$.

Silnym rysem posługi pasterskiej o. R. Kiernickiego była duszpasterska opieka nad dziećmi i młodzieżą ${ }^{63}$. Szczególnie dbał, aby były one dobrze przygotowywane do spowiedzi i Pierwszej Komunii Świętej. Zorganizował więc grupę katechetek $^{64}$, których zadaniem było nauczanie w miejscu zamieszkania dzieci pacierza, katechizmu, przykazań Bożych, aby potem świadomie przystąpiły do sakramentu pokuty i Eucharystii ${ }^{65}$. W 1974 r. zakonnik otrzymał do pomocy ks. Ludwika Kamilewskiego ${ }^{66}$, który posługę w katedrze lwowskiej pełnił do stycznia 1991 r. Dnia 6 stycznia 1991 r. o. Rafał został mianowany biskupem tytularnym Dura i sufraganem arcybiskupa lwowskiego Mariana Jaworskiego. W swoich wspomnieniach z 1991 r. napisał: „Objąłem katedrę w 1948 roku. Kończę więc tu 43 rok pracy. Kiedy przyszedłem do katedry, jeden z dwóch księży powiedział: «Wkładaj sutannę i idź spowiadać!» I tak się zaczęło" ${ }^{\circ}$.

${ }^{60}$ Krętosz, Katedra obrzadku łacińskiego we Lwowie, s. 73.

${ }^{61}$ Relacja ks. L. Kamilewskiego.

${ }^{62}$ Madała, Polscy księża katoliccy $w$ więzieniach i łagrach sowieckich, s. 80.

${ }^{63}$ Ponieważ prawo sowieckie zabraniało katechizować dzieci i młodzież do 18. roku życia.

${ }^{64}$ Najbardziej znane i zasłużone w tej pracy były siostry Irena i Jadwiga Zappe.

Zappe Irena (1919-2013) - ur. w Zaleszczykach. W 1938 r. rozpoczęła studia na Uniwersytecie Jana Kazimierza we Lwowie, które ukończyła w 1941 r. We wrześniu 1939 r. jako harcerka uczestniczyła w obronie Lwowa, pełniąc służbę sanitariuszki. Od 1942 r. angażowała się w działalność konspiracyjną w Armii Krajowej. Wraz z siostrą Jadwigą organizowały od 1952 r. w swoim mieszkaniu naukę religii, języka polskiego, historii oraz różnego rodzaju pomoc dla najbiedniejszych, np. dożywianie i odzież itp. W 1976 r. oskarżono siostry Zappe o prowadzenie nielegalnej katechezy i działalność antypaństwową. Przeprowadzone śledztwo nie wykazało „działalności zorganizowanej finansowanej z zagranicy”. Irena Zappe zmarła 4 lipca 2013 roku we Lwowie. IPN, Irena (19192013) i Jadwiga Zappe, https://ipn.gov.pl/pl/aktualnosci/konkursy-i-nagrody/nagroda-kustosz-pamieci/2008/24256,Irena-19192013-i-Jadwiga-Zappe.html (dostęp: 4.07.2019); K. Szymański, Duchem zawsze młoda, „Kurier Galicyjski”, (2016) nr 7 (251), s. 25.

${ }^{65}$ Relacja ks. L. Kamilewskiego.

${ }^{66}$ Ludwik Kamilewski (1946-2019) - urodził się w Kazachstanie, w polskiej rodzinie deportowanej w 1936 r., która w 1948 r. powróciła do Połonnego. Po ukończeniu szkoły i odbyciu służby wojskowej wstąpił do seminarium duchownego w Rydze na Łotwie, gdzie 26 maja 1974 r. przyjął święcenia kapłańskie. Był wikariuszem w katedrze we Lwowie. Przyczynił się do odzyskania przez katolików kościołów w obwodzie lwowskim i wołyńskim w latach 90. XX wieku, m.in w Maniewiczach, Ołyce, Cumaniu, Beresteczku, Lubieszowie i Żytomierzu (św. Wacława, gdzie przez 17 lat był proboszczem oraz katedry św. Zofii). W marcu 1991 r. został pierwszym po wojnie proboszczem parafii katedralnej Świętej Trójcy Świętej i śś. Apostołów Piotra i Pawła w Łucku. W latach 19912000 był dziekanem łuckim i dziekanem dekanatu żytomierskiego. Zmarł w Łucku. Pochowany został 24 stycznia 2019 r. w rodzinnym mieście Połonne. L. Kamilewski, Odrodzenie Kościoła rzymskokatolickiego w obecnym dekanacie tuckim (1989-1997), w: Polacy i Kościót rzymskokatolicki na Wolyniu w latach 1918-1997, red. L. Popek, Lublin 1999, s. 109-112.

${ }^{67}$ Osadczy, Kościót wyznawców, s. 196. 
W uznaniu zasług o. R. Kiernickiego na polu kościelnym i duszpasterskim został on odznaczony: Krzyżem Partyzanckim, Złotym Krzyżem Zasługi z Mieczami, Złotym Medalem Opiekuna Miejsc Pamięci Narodowej, odznaczeniem Zasłużonego dla Kultury Polskiej i Nagrodą Specjalną im. Włodzimierza Pietrzaka ${ }^{68}$.

Ojciec Święty Jan Paweł II podczas pielgrzymki do Polski, w dniu 3 czerwca 1991 r. w Lubaczowie, przywołując posługę o. Rafała, powiedział: „Przez tyle lat, dziesięcioleci, przez tyle cierpień i upokorzeń, wierny stróż tego skarbu, tego znaku tożsamości Kościoła, jakim jest prastara, lwowska katedra łacińska" ${ }^{69}$.

Ojciec R. Kiernicki zmarł dnia 23 listopada 1995 r. Został pochowany w krypcie katedry lwowskiej, której poświęcił 46 lat pracy i życia ${ }^{70}$.

Sygnałem pewnego przełomu w Związku Sowieckim, był fakt, że dnia 24 maja 1984 r. papież Jan Paweł II mianował administratorem apostolskim w Lubaczowie - będącym stolicą biskupią „Archidiecezji Lwowskiej w Lubaczowie”, ks. Mariana Jaworskiego, rodowitego lwowianina, wówczas rektora Papieskiej Akademii Teologicznej w Krakowie. W sierpniu 1987 r. z polecenia abpa M. Jaworskiego udał się ,prywatnie” do Lwowa jego sekretarz ks. Marian Buczek. Został przyjęty serdecznie przez proboszcza katedry o. R. Kiernickiego i wikariusza ks. Ludwika Kamilewskiego. Ks. M. Buczek odprawił wówczas mszę św. w kaplicy św. Józefa, przy zamkniętych drzwiach katedry. Tylko jeden raz udało mu się koncelebrować przy ołtarzu głównym katedry wraz ks. L. Kamilewskim. Kapłani lwowscy w kanonie mszy św. wymieniali imię biskupa Mariana z Lubaczowa, świadomi, że jest to ich zwierzchnik ${ }^{71}$.

Niezależnie od doznawanych przez Kościół w latach komunizmu trudności kontynuowano pracę duszpasterską we Lwowie. Aby wspomóc o. R. Kiernickiego, będącego już w podeszłym wieku, przyjeżdżali już w latach 70 . XX wieku na prywatne zaproszenia kapłani z Polski lub księża wyświęceni w Rydze.

Po zakończeniu II wojny światowej zaczęły się najcięższe lata dla ludzi wierzących, w tym dla Lwowa i łacińskiej katedry. Katedrze, jako matce kościołów w diecezji, groziło zamknięcie, a duchowni doznawali szykan i terroru nowej, sowieckiej władzy. Wśród duszpasterzy walczących o nieprzerwane funkcjonowanie tej świątyni szczególne miejsce zajął proboszcz - legenda duszpasterstwa lwowskiego - o. R. Kiernicki. W dniu 4 maja 2012 r. w lwowskiej katedrze łacińskiej został otwarty jego proces beatyfikacyjny.

\section{Zakończenie}

Gdy w dniu 2 marca 1991 r. w katedrze lwowskiej odbywała się konsekracja pierwszych powojennych biskupów, wielu zadawało sobie pytanie, czy to się dzieje naprawdę? Wśród nowo konsekrowanych biskupów był ks. Markijan Trofimiak i o. Rafał Kiernicki. Podczas jednej z odprawianych liturgii pogrzebowych

\footnotetext{
${ }^{68}$ Kiernicki Władysław, w: Dzwonkowski, Leksykon duchowieństwa, s. 319.

${ }^{69}$ Tamże.

${ }^{70}$ Vitold-Yosif Kovaliv, Odrodzenie struktur Archidiecezji Lwowskiej pod koniec XX wieku, „Wołanie z Wołynia.”, 18 (2012) nr 5 (108) - B, wrzesień-październik 2012, s. 25.

${ }^{71}$ Tamże, s. 26-27.
} 
o. Rafał postawił raz pytanie: „czy będzie jeszcze komu mnie pogrzebać?” Wspomnienie to staje się znamienne, w historycznym dniu dla Kościoła katolickiego, miasta Lwowa i miejscowych katolików, gdy otoczony licznym gronem duchowieństwa i w wypełnionej po brzegi katedrze, o. R. Kiernicki otrzymywał sakrę biskupią.

Kiedy w 1944 r. Lwów zajęły władze sowieckie, Kościół katolicki został skazany na unicestwienie. Stało się jednak inaczej. Odrodzenie się Kościoła, jego żywotność, stałość wiernych, bohaterstwo kapłanów, którzy zostali i wiernie służyli Kościołowi, przypłacając to niejednokrotnie karami, szykanami, więzieniem i zsyłkami, dla wielu jest fenomenem. Z pewnością wszystkie te czynniki złożyły się na niezwykłe dzieje Kościoła na ziemi lwowskiej.

\section{REFERENCES / BIBLIOGRAFIA}

Baziak Jolanta, Wygnaniec. Tułacz a może Ikar, Bydgoszcz 2019.

Bosiacki Adam, Utopia, władza, prawo. Doktryna i koncepcje prawne „,bolszewickiej” Rosji 1917-1921, Warszawa 1999.

Buczek Marian, Biskup Jan Cieński - tajemny biskup w Złoczowie, „Kurier Galicyjski” z 17-29.11.2017, nr 21 (289), s. 20-21.

Buchek Marian, Parafii, kostely ta kaplytsi. Lvivska oblast, t. 1, Lviv 2004.

Budz Kateryna, Ukrajnska Greko-Katolytska Cerkva v Galytchyni (1946-1968): strategij vyzhyvannia ta oporu y pidpilli, Kyiv 2016.

Dzwonkowski Roman, Religia i Kościót katolicki w ZSRS 1917-1991. Kronika, Lublin 2010.

Frucht Sergiusz, Lwów, Lwów-Wrocław 2003.

Gajewski Stanisław, Iuventus Chistiana, Juventus, w: Encyklopedia katolicka, t. 7, red. J. Duchniewski i in., Lublin 1997, kol. 564-565.

Hałuniewicz Zygmunt, w: R. Dzwonkowski, Leksykon duchowieństwa polskiego represjonowanego w ZSRS 1939-1988, Lublin 203, s. 253-254.

Kaczorowski Bartłomiej, Zabytki starego Lwowa, Warszawa 1999.

Kamilewski Ludwik, Odrodzenie Kościoła rzymskokatolickiego w obecnym dekanacie tuckim (1989-1997), w: Polacy i Kościót rzymskokatolicki na Wolyniu w latach 19181997, red. L. Popek, Lublin 1999, s. 109-112.

Kiernicki Władysław, w: R. Dzwonkowski, Leksykon duchowieństwa polskiego represjonowanego w ZSRS 1939-1988, Lublin 2003, s. 318-319.

Kovaliv Vitold-Yosif, Odrodzenie struktur Archidiecezji Lwowskiej pod koniec XX wieku, „Wołanie z Wołynia”, 18 (2021) nr 5 (108) - B, s. 22-42.

Krętosz Józef, Katedra obrzadku łacińskiego we Lwowie i jej proboszcz o. Rafat Kiernicki OFMConv w latach 1948-1991, Katowice 2003.

Kuczyńska Maria Bożena, „,Nazywano Ojca Szaleńcem Bożym”. Bp. Wtadystaw Rafat Kiernicki OFMConv. Duszpasterz i zesłaniec (1912-1995), „Zesłaniec”, 64 (2015) s. 25-37.

Lwów. Przewodnik dla zwiedzających miasto, oprac. A. Medyński, Lwów 1937.

Machniak Jan, Abp Józef Bilczewski. Pasterz Kościoła Lwowskiego, Kraków 2001.

Madała Tadeusz, Polscy księża katoliccy w więzieniach i łagrach sowieckich od $1918 \mathrm{r}$. Materiaty do stownika biograficznego, Lublin 1996. 
Mandziuk Józef, Z dziejów archidiecezji lwowskiej, „Saeculum Christianum”, 2 (1995) nr 2, s. 35-59.

Modzelewska Bożena, Osadczy Włodzimierz, Lwów. 1 Miasto, w: Encyklopedia katolicka, t. 11, red. E. Ziemann, Lublin 2006, kol. 303-312.

Muzyka Marian, Ks. Karol Jastrzębski 1882-1962. Katecheta, duszpasterz, promotor kultu Bożego Miłosierdzia w Archidiecezji Lwowskiej, Lwów 2017.

Nicieja Stanisław Sławomir, Cmentarz Lyczakowski we Lwowie w latach 1786-1986, Wrocław 1988.

Olechowski Piotr, Między ottarzem a gabinetem partyjnym. Kościót rzymskokatolicki w sowieckim Lwowie w latach 1953-1959 w świetle raportów petnomocnika Rady ds. Kultów Religijnych w obwodzie lwowskim, „Pamięć i Sprawiedliwość”, 16 (2017) nr 1 (29), s. 176-200.

Osadczy Włodzimierz, Kościoła katolickiego na Ukrainie dole i niedole. Doświadczenie, dzień dzisiejszy, problemy i perspektywy, w: Kościól katolicki na Wschodzie w warunkach totalitaryzmu i posttotalitaryzmu, red. A. Gil, W. Bobryk, Siedlce-Lublin 2010, s. $87-108$.

Osadczy Włodzimierz, Kościól wyznawców. Kapłani archidiecezji lwowskiej obrzadku lacińskiego w latach 1945-1991, w: Prorocy Europy Środkowo-Wschodniej XX wieku, red. S.C. Napiórkowski OFMConv, Lublin 2009, s. 187-204.

Paprocki Henryk, Panichida, w: Encyklopedia katolicka, t 14, red. E. Gigilewicz, Lublin 2010, kol. 1214.

Paluch Janusz M, Ojciec Rafat, „Cracovia Leopolis”, 7 (2001) nr 3 (27), s. 9, 12.

Platowska-Sapetowa Inga, Cudowny Obraz N.P. Maryi Laskawej z Archikatedry Lwowskiej w Prokatedrze w Lubaczowie, Rzeszów 1991.

Płoszyński Stanisław, w: R. Dzwonkowski, Leksykon duchowieństwa polskiego represjonowanego w ZSRS 1939-1988, Lublin 2003, s. 488-489.

Rechowicz Marian, Baziak Eugeniusz, w: Encyklopedia katolicka, t. 2, red. F. Gryglewicz, R. Łukaszyczyk, Z. Sułowski, Lublin 1985, kol. 127.

Renik Krzysztof, Podpolnicy. Rozmowy z ludźmi Kościoła na Litwie, Lotwie, Białorusi i Ukrainie 1990-1991, Warszawa 1991.

Seweryn Ludwik, w: Encyklopedia wiedzy o jezuitach na ziemiach Polski i Litwy 15641995, red. L. Grzebień, Kraków 1996, s. 612.

Siepak Elżbieta, Kowalska Faustyna. 1. Życie, 2. Objawienia prywatne, w: Encyklopedia katolicka, t. 9, red. A. Szostek, Lublin 2002, kol. 1085.

Skowyra Marian, Jubileusz sześćdziesięciolecia śmierci arcybiskupa metropolity Bolesława Twardowskiego i dziewiąta rocznica śmierci bpa Rafała Kiernickiego, „Radość Wiary" 2004, 7(43), s. 7.

Sokolnicka-Izdebska Zofia, Historia Kościoła we Lwowie od 1939 roku. Cz. 1, „Cracovia Leopolis", (1996) R. 2, nr 2(6), s. 14-17.

Sokolnicka-Izdebska Zofia, Historia Kościoła we Lwowie od 1939 roku. Cz. 2, „Cracovia Leopolis", (1996) R. 2, nr 3(7), s. 12-16.

Sokolnicka-Izdebska Zofia, Historia Kościoła we Lwowie od 1939 roku. Cz. 3, „Cracovia Leopolis", (1996) R. 2, nr 4(8), s. 18-19.

Sokolnicka-Izdebska Zofia, Historia Kościoła we Lwowie od 1939 roku. Cz. 4, „Cracovia Leopolis" (1997) R. 3, nr 1(9), s. 46-48.

Szymański Józef, Dwadcatki - organy wykonawcze organizacji religijnych $w$ sowieckim systemie represji (Obwód Winnicki na Podolu, 1944-1964), „Roczniki Teologiczne”, 50 (2003) z. 4, s. 171-195.

Szymański Krzysztof, Duchem zawsze młoda, „Kurier Galicyjski”, (2016) nr 7 (251), s. 25. 
Tokarski Jacek, Ilustrowany przewodnik po zabytkach kultury na Ukrainie, t. 1, Warszawa 2000.

Truszkowski Zygmunt, w: R. Dzwonkowski, Leksykon duchowieństwa polskiego represjonowanego w ZSRS 1939-1988, Lublin 203, s. 601-602.

Urban Wincenty, Archidiecezja lwowska, w: Życie religijne w Polsce pod okupacja 19391945. Metropolie wileńska i lwowska, zakony, red. Z. Zieliński, Katowice 1992, s. 91171.

Wołczański Józef, Bazylika Metropolitalna obrządku łacińskiego we Lwowie, „Radość Wiary", (2001) nr 1 (29), s. 10.

Wołczański Józef, Kapłani męczennicy. Świadkowie wiary kościoła lwowskiego ksiądz kanclerz Zygmunt Hatuniewicz (1889-1974), „Radość Wiary”, (1999), nr 3-4 (23-24), s. 17.

Wołczański Józef, Katalog grobów duchowieństwa i sióstr zakonnych obrządku łacińskiego i greckokatolickiego na Cmentarzu Janowskim we Lwowie, „Nasza Przeszłość”, 88 (1997) s. 255-294.

Wołczański Józef, Ksiadz Biskup Jan Olszański. Duszpasterz - Patriota - Człowiek, w: Pasterz i twierdza. Księga jubileuszowa dedykowana księdzu biskupowi Janowi Olszańskiemu orydnariuszowi diecezji w Kamieńcu Podolskim, red. J. Wołczański, Kraków-Kamieniec Podolski 2001, s. 9-19.

Wołczański Józef, Między zagłada a przetrwaniem. Wybrane obiekty sakralne archideicezji lwowskiej i diecezji przemyskiej obrzadku łacińskiego na Ukrainie Zachodniej 1945-1991, Kraków 2005.

Wołoszyn Jacek, Podstawy antysystemowe mtodzieży $w$ wybranych państwach socjalistycznych Europy Środkowo-Wschodniej w latach 1945-1956 - zarys problematyki, „Rocznik Instytutu Europy Środkowo-Wschodniej”, 18 (2020) z. 4, s. 203-219.

\section{Netografia}

Irena (1919-2013) i Jadwiga Zappe, https://ipn.gov.pl/pl/aktualnosci/konkursy-i-nagrody/ nagroda-kustosz-pamieci/2008/24256,Irena-19192013-i-Jadwiga-Zappe.html (dostęp: 4.07.2019).

Sanktuarium Swiętego Antoniego, https://antoni.lviv.ua/pl/ksieza-w-nieprzerwanej-sluzbie/ (dostęp: 26.02.2021).

\section{Relacje}

Relacja Janiny Zamojskiej, Lwów 15 XII 2007 r. (zb. wł. autora).

Relacja ks. Ludwika Kamilewskiego, Łuck 9 IX 2019 r. (zb. wł. autora). 


\begin{abstract}
The article presents selected aspects of the social and religious life of the Roman Catholic community of Lviv in the Soviet Union over the years 19451991. The Catholic Church in the Polish territories annexed by the USSR was subordinated to communist legislation, which fought religion and spread atheism. Ecclesiastical structures were dismantled, and the clergy and believers were repressed. Despite this, the Church as a community of believers continued and used various opportunities for continued activity. The article presents the attitudes of the Lviv clergy towards the Soviet authorities and their covert pastoral activity among the faithful. Particular attention was paid to the clergy who became symbols of the Lviv pastoral care after World War II. They were priests: Karol Jastrzębski, Stanisław Płoszyński, Zygmunt Hałuniewicz and Rafał Władysław Kiernicki, a Franciscan.
\end{abstract}

Keywords: Lviv; Lviv cathedral; Soviet Ukraine, priest Karol Jastrzębski, Rev. Stanisław Płoszyński; Rev. Zygmunt Hałuniewicz; Rafał Władysław Kiernicki 